\title{
Hybrid Identity in Transition and Crisis:A Homi Bhabhaian Post Colonial Reading of Richard Wright's Black Boy
}

\author{
Fateme Rahimi, MA \\ Graduate of English language and Literature \\ Dr. Hossein Sabouri \\ Associate Professor, University of Tabriz, Iran
}

\begin{abstract}
The present article seeks to critically examine Richard Wright's Black Boy under the light of Homi Bhabha's hybridity. It tries to reexamine the way this notion has been defined and inspect the way one's familiarity with this notion informs one's reading of Black Boy. The contemporary age observes a wide variety of thinkers dealing with the notion of hybridity, among whom Bhabha is the key figure. Hybridity is among the major key terms which affect postcolonial discourse. This article surveys how hybridity is defined in interaction with related concepts and demonstrates the way hybridity informs the reading of the different layers of meaning in this work. At first it examines historical context in which the story takes place and the historical perspective of black writing narrative and the effects of racism and oppression, which include poverty and hunger and the ways through which the blacks reacted to racism. Further, it reviews materials relevant to this article and also shed more light in the circumstances that brought the black to the unfriendly society in which they found themselves today. And finally, it aims to explore the characters mainly the protagonist of the story, Richard; and also others to have the role on Richard's growth and the way of shaping his worldview. Through the depiction of his own childhood, Wright universalizes childhood of many African-American children growing up in the old South in the first half of the twentieth century.
\end{abstract}

Keywords: Black Boy, Richard Wright, Homi Bhabha, hybridity, Post colonialism

\section{INTRODUCTION}

The present article seeks critically colonialism and racism of the African Americans to demonstrate the effects of them on the way of living of the Blacks; and the ambiguity and duality in the identity caused under the era and circumstances' which results in hybrid identity. Richard Wright, a prominent early 20th century African American writer, perceived imminent peril on the horizon for his native country. He believed that the segregation dividing Blacks and Whites and the racism that split the country would have dire consequences if left unchecked. Consequently, Wright set out to write didactic books illustrating the conditions African Americans faced in the United States. (HatcherJr. 6) Without doubt, Homi K. Bhabha's 'hybridity' is one of the most vital concepts in cultural criticism today.(Mizutani 1) "A discrimination between the mother culture and its bastards, the self and its doubles, where the trace of what is disavowed is not repressed but repeated as something different-a mutation, a hybrid."(Bhabha 1985 153) Hybridity is the sign of the productivity of colonial power, its shifting forces and fixities; it is the name for the strategic reversal of the process of domination through disavowal. It is the revaluation of the assumption of colonial identity through the repetition of discriminatory identity effects. It displays the necessary deformation and displacement of all sites of discrimination and domination. The present article aims to critically explore Richard Wright's Black boy in terms of the Bhabhaian notion of Hybridity based on post-colonial reading to show that racism and colonialism can have traumatic effect on the identity of the postcolonial people.

\section{BHABHAIAN HYBRIDITY IN RICHARD WRIGHT'S BLACK BOY}

Richard Wright (1908-1960) came from the most impoverished of peasant circumstances in Natchez, Mississippi. He was widely regarded intellectual activist and cultural critic, who engaged in radical politics on behalf of the liberation of Black people in Africa and in America. As a writer of fiction and non-fiction, Wright almost single-handedly created new, progressive, and assertive images of Black people that challenge traditional racist stereotype (Hayes4).Richard Wright's outlook on the 
world was badly influenced by the social-cultural conditions of the period in which he was born. One has to take into consideration that Wright was born in the USA at the very beginning of the 20th century (1908), the century that was preceded by 60 years of never ending disputes leading to the Civil War between the North and the South. The war had two main results. It put an end to slavery and it also decided that America was a single nation. However, the old landed aristocracy started to gain more and more political and economic control over the South. (Hovad 11)

African American writing continued to enter the mainstream with the protest novels of 1940s.Spurred by Depression and the failure of Jim Crow in the south, naturalist author Richard Wright furiously attacked white American society at the start of the Civil Right movement in works such as Native Son (1938) and Black Boy (1945).( Guerin et al 291) In native son, Wright depicts in graphic physical and psychological details the realities of a young black man's life under the pressure of a racist environment. In Black Boy, one might say that Wright turns the novelist's gaze to his own life, providing "A Record of Childhood and Youth" that is at once informative as a historical account and gripping in the same way a novel can be. Wright uses his autobiography not only to recount significant experiences in his life but also to record his emotional and psychological reactions to those experiences, his intellectual awakening, his hunger for meaningful life, and his condemnation of American racism. In his attempt to capture the significance of his own life, Wright creates in Black Boy a profoundly moving record of his remarkable life. (Telgen56)

Racism as a problem among individuals is a familiar topic in literature. Black Boy, however, explores racism not only as an odious belief held by odious people but also as an insidious problem knit into the very fabric of society as a whole. Throughout the work, we see Richard observe the deleterious effects of racism not only as it affects relations between whites and blacks, but also relations among blacks themselves. Wright entitles his work Black Boy primarily for the emphasis on the word "black": this is a story of childhood, but at every moment we are acutely aware of the color of Wright's skin. In America, he is not merely growing up; he is growing up black. Indeed, it is virtually impossible for Richard to grow up without the label of "black boy" constantly being applied to him. Whites in the novel generally treat Richard poorly due to the color of his skin. Even more important, racism is so insidious that it prevents Richard from interacting normally even with the whites who do treat him with a semblance of respect or with fellow blacks. (Kuriakose 16)

Before dealing with the ways familiarity with the notion of hybridity affects one's reading of Black Boy, one should examine the background of this work and the impacts movements such as post colonialism have on the formation of this work. The term 'post-colonial' is resonant with all the ambiguity and complexity of the many different cultural experiences it implicates. It addresses all aspects of the colonial process from the beginning of colonial contact. (Ashcroft 2) Post-colonial literatures are a result of the interaction between imperial culture and the complex of indigenous cultural practices. (Ibid 1) Once colonized peoples had cause to reflect on and express the tension which ensued from this problematic and contested, but eventually vibrant and powerful mixture of imperial language and local experience, post-colonial 'theory' came into being. (Ibid)

The Post - colonial Literature and theory investigate what happens when two cultures clash and one of them with accompanying ideology empowers and deems itself superior to other. It usually excludes literature that represents either British or American viewpoints, and concentrates on Writings from colonized cultures in Australia, New Zealand, Africa, South America, and other places and societies that were once dominated by European cultural, political and philosophical tradition. (Sawant 120) Homi K. Bhabha is a well-acknowledged man of learning in cultural studies and theories concerning colonialism and post colonialism.

Homi K. Bhabha was born in Mumbai in a family of Parsi background. Bhabha received a B.A. from Bombay University, and an M.A., M.Phil., and D.Phii. from Christ Church, Oxford University. Bhabha has taught at the University of Sussex, Princeton University, the University of Pennsylvania, Dartmouth College, and the University of Chicago. Besides having a successful career as a Harvard professor and as a writer of two influential books - The Location of Culture and Nation and Narrations, he has published widely in journals including New Formations, October, Oxford Literary Review and Screen. He sits on the editorial board of, amongst others, October, Critical Inquiry, and New Formations, and is a regular contributor to Art forum. His study of oppressions, traumatic colonial feelings, and impact of other powerful factors which produce another cultures, creeds, habits 
and civilizations are deeply influenced by Foucault, Edward W Said, Jacques Derrida, Lacan and Sartre. His theoretical postulations are based on fundamental but experimental concepts of liminality, hybridity, mimicry and ambivalence which are a stimulant of cultural productivity. (Rahaman)

While Said discusses the differences and oppositions between colonizers and colonized, Bhabha often examines their points of similarity. (Berastegui Wood 142)

Part culture, partial culture, is the contaminated yet connective tissue between culturesat once the impossibility of culture's containedness and the boundary between. It is indeed something like culture's 'in-between', baffling both alike and different. (Bhabha Culture, Hall 54)

The term 'hybridity' has been most recently associated with the work of Homi K. Bhabha, whose analysis of colonizer / colonized relations stresses the inter-dependence and mutual construction of their subjectivities. 'Hybridization' is a kind of negotiation, both political and cultural, between the colonizer and the colonized. (Sawant 123) "Homi K. Bhabha has infused thinking about nationality, ethnicity, and politics with poststructuralist theories of identity and indeterminacy" (Dehdari 135) According to Habib, the tenets are "a challenging of the notion of fixed identity, the undermining of binary oppositions, and an emphasis on language and discourse" together with the power relations in which these are imbricated "as underlying our understanding of cultural phenomena" (Ibid). One further point of significance concerning the true nature of interaction between the colonizer and the colonized is that apparently, the colonized are the only victims of colonial system; however, there is a problem in front of the colonizer which makes them victim as well. This problem may be: fading identity. (Ibid 137)

As Homi Bhabha says:

Hybridity is the revaluation of the assumption of colonial identity through the repetition of discriminatory identity effects. (...) It unsettles the mimetic or narcissistic demands of colonial power but re-implicates its identifications in strategies of subversion that turn the gaze of the discriminated back upon the eye of power. For the colonial hybrid is the articulation of the ambivalent space where the rite of power is enacted on the site of desire, making its objects at once disciplinary and disseminatory —or, in my mixed metaphor, a negative transparency. (Signs 154)

Fading identity can be a direct result of hybridity in culture. Fading identity may lead to identity crisis both in the colonizing and colonized cultures. The fact that hybridity "threatens the authority which is based on categorizations of difference" is among the most dramatic aspects of Bhabhaesque hybridity. Hybridity "confuses the signs of difference as signs of authority". Many of Bhabhaesque definitions of the notion of hybridity locate in The Location of Culture. (Dehdari 137) Hybridity enables the establishment of communication between cultures. It is obvious that the two cultures cannot enter a proper interaction via the application of absolute domination on the side of one culture. There are cultural specifications the colonizing cultures, consciously or unconsciously, take from the colonized cultures. The Location of Culture is Bhabha's seminal work in which he gives many of the definitions of the notion of hybridity and accounts of the diverse aspects of this concept. The most comprehensive part of it concerning the definition of the notion of hybridity in Bhabha's works is the following excerpt from "Signs Taken for Wonders" in which Bhabha says:

Hybridity is the sign of the productivity of colonial power, its shifting forces and fixities; it is the name for the strategic reversal of the process of domination through disavowal (that is, the production of discriminatory identities that secure the pure and original identity of authority). (154)

In Black Boy Richard Wright is controlled by the place where he lived and by the time as well. He was born into an era that was a nightmare for African-American people. However, he believed in his powers and he did not want to give it up. That was the reason why he was longing for education, reading and writing. He wanted to prove that he is talented and he did not want to make peace with his ordeal. He wanted to fight against the conditions in which he was growing up and he wanted to reach something valuable in his life. (Hovad 8) 
Wright and other black characters are treated by the whites as or even worse than animals. Wright recounts how he lost his job on the basis that he called a white man by name without adding Mr. to his name. The whites deny the blacks what is considered "a white man's job", thereby depriving them a means of livelihood. Blacks are treated as animals even right from the time of slavery. Richard's Granny was named by her slave master:

"What was Granny's name before she married Grandpa?" "Bolden" "Who gave her that name?" "The white man who owned her". (Wright 42) This conversation between Richard and his mother makes him know that he is actually a descendant of slaves. (Umulkhulsum 37) The blacks, even in Richard's days are still used as slaves. They are seen not just as slaves but also for amusement. Wright asserts that "I suppose it is fun for white man to see niggers fight". He captures an incident where Mr. Olin, one of the foremen in his office instigated a fight between him and Harrison, another black boy. Mr. Olin promises the winner five dollars just for the two boys to fight themselves while the whites watch them and laugh. (Umulkhulsum 38)

Wright has a harsh criticism against the White South and the way they treated him:

The white South said that it knew 'niggers,' and I was what the white South called a 'nigger.' Well, the white South had never known me- never known what I thought, what I felt. The white South said that I had a 'place' in life. Well, I had never felt my 'place'; or, rather, my deepest instincts had always made me reject the 'place' to which the white South had assigned me (227)

Richard Wright acknowledged that he was a product of the West, albeit a person of African descent. He explained:

Since I'm detached from, because of racial conditions, the West, why do I bother to call myself Western at all? What is it that prompts me to make identification with the West despite the contradiction involved? The fact is I really have no choice in the matter. Historical forces more powerful have shaped me as a Westerner. I have not consciously elected to be a Westerner. I have been made into a Westerner. Long before I had the freedom to choose, I was molded a Westerner. It began in childhood. And the process continues. (qtd. In Kunnie 7)

Throughout the work, we see Richard observe the deleterious effects of racism not only as it affects relations between whites and blacks, but also relations among blacks themselves. Wright entitles his work Black Boy primarily for the emphasis on the word "black": this is a story of childhood, but at every moment we are acutely aware of the color of Wright's skin. In America, he is not merely growing up; he is growing up black. Indeed, it is virtually impossible for Richard to grow up without the label of "black boy" constantly being applied to him.

Wright's background was characterized with a sense of powerlessness of the black towards the white. He came to realize that the white were the superior ones who dictated what happened in the black world. He goes against this by advocating for a sense of cultural consciousness and nationalism among the blacks. (Umulkhulsum 32) Wright's reactions are exhibited in his character, for example, Richard in Black Boy refused to accept the superiority of the white. Wright's reaction towards the black is love for the African culture and he also feels disgust for Africans who have turned themselves into puppets in the hands of the white. Wright's attitude towards the black's world is also that of resentment and disgust. Most of his character can be termed "free-floating outsider" who have a fixation about the white world. (Ibid 33)

It is Richard's experience that makes him a writer. Since he is alienated and isolated from both worlds, he takes to reading everything he could lay hands on, from magazine, newspapers, novels etc. After Richard tries his hands on some few menial jobs, he came to realize the society is a plain one which holds no future for the uneducated blacks. Richard's dream to become a writer is to be able to express the dominating spirit of the whites, the idea of white superiority and to tell of the various ways through which the blacks are exploited. To achieve this dream, Wright moves from the southern part of America to the northern part where he hopes things will get better. It was there he begins to write to antagonize slavery and the pervading racial discrimination (Ibid 48)

Wright has many internal conflicts throughout his life. Many of these are related to his place in a racist society. Wright struggles with how so many black people around him are sunk in poverty, with 
nowhere to turn except for their equally poor families who are also mired in the stereotype of the dumb and submissive black man and are subject to racist Jim Crow laws, particularly in the South. Wright constantly questions his place in this society. He also finds that many black people steal, lie, and cheat in order to get a little bit ahead or to even just survive. Many times Wright is faced with opportunities to do this, and many times he refuses. There are a few notable moments when he succumbs to this temptation, such as when he takes advantage of his white boss in the movie theater, steals and sells fruit preserves and a stolen gun. He does this in order to move to the North and get out of the highly volatile racial situation in the South, hardly a trifling cause. (Sorensen 4)

Not only is Wright struggling internally with his thoughts about his society, but he faces countless external struggles as well. These come in the form of violence. He meets with violence at almost every other moment in his life. As a small child, this violent conflict comes when he challenges the commands of his parents and gets whipped. As he gets older, he must fight to establish his place in the schoolyard. When he begins to work, he is constantly in the middle of violent racial prejudice with his coworkers. Many times, particularly when he works in the optical shop in Mississippi, he becomes the victim of discrimination and petty tricks played on him by the other white employees. Even when he moves north to Memphis and Chicago he is constantly struggling against the black man's place in society, which is often a very literal place: at the back of the theater, in separate facilities that are in terrible condition. Wright overcomes some of this conflict as he joins the Communist party and becomes the secretary of the local club, but still faces it in his everyday life as he tries to earn a living for his family in the times of the Great Depression. Wright faces a very literal, violent struggle against the world to survive. (Black Boy: Richard Wright)

\section{CONCLuSion}

To sum up, Wright gives us an insight into racism, the psychological and sociological trauma that the people who live in racist society face. He projects revolution as the only means to freedom and through which people discriminated against can get self identity and recognition in a racist society. Furthermore, it is realized that Richard, the protagonist in Black Boy portrays the suffering and manipulations of the African by the whites as a result of the color difference. As a product of racist society, Richard Wright tries to provide solutions to the racial problems he faced. Richard Wright had the spirit of radicalism in him; he preferred to go hungry all day than to accept food from the whites. Also, in the office, he say that white man as his equal and refused to be a puppet like his fellow black friends. Wright's actions showed that there is no difference between the two opposing groups; and that people should not be discriminated against because of their skin color. (Umulkhulsum 53)This article has dealt with the study of racism and oppression which was common in the postcolonial era of America specifically in the south in combination with conditions of black African-Americans which in this article results to a hybridity in the identity in Richard Wright's Black Boy.

As one who saw himself as a Black man of modern Western civilization, Richard Wright also knew that racism had not allowed him, or other Black people, actually to enjoy the full meaning of modern Western culture. By using the phrase, "in it but not of it," Wright captured his own sense of homelessness and rootlessness to characterize his existence as a modern Westernized Black man. He also employed this outsider consciousness as a lens with which to analyze the existential condition of all Third World elites who were caught in the cauldron of Western civilization's white supremacy. This experience of being simultaneously inside and outside of American culture produced Wright's third force or view of the world. (Hayes 19)

To sum up, we could say that Black Boy is a good representation of the hybridity process. On the one hand, it shows how hybridity determines discourse strategies of both, the colonizer and the colonized. On the other hand, it proves that hybridity can be an important emancipating resource from some old repressive discourses. But Black Boy is also an example of how racial and class discourses affect each other. It is difficult to talk about hybridity without paying attention to social class issues. The central theme of this article is no longer the struggle of the blacks for survival and rights to meaningful living, but also a more philosophical approach to the struggle for emancipation, self determinism and cultural self identity which was trapped and influenced by colonization and racism specifically in the same era and time period. (Berastegui 146)

\section{REFERENCES}

International Journal on Studies in English Language and Literature (IJSELL) Page 28 
[1] Aschroft, Bill, Gareth Griffiths, Helen Tiffin, Ed. The Post-Colonial studies Reader. New York: Taylor \& Francis e-library, 2003.

[2] Aschroft, Bill, Gareth Griffiths, Helen Tiffin. The empire Writes Back. London: Routledge, 1989.

[3] Berastegui Wood, Jorge. The Analysis of Hybridity in My Beautiful Launderette. 2007

[4] Bhabha, Homi K. "Culture's In-Between". (1996) Ed. Stuart Hall \& Paul Du Gay.Questions of Cultural Identity. Sage Publication, London, 2003.

[5] "Of Mimicry and Man: The Ambivalence of Colonial Discourse" MIT Press, Vol. 28, Date of access: 2015. [http://www.jstor.org/stable/778467]

[6] "Signs Taken for Wonders: Questions of Ambivalence and Authority under a Tree outside Delhi”. Critical Inquery, Vol. 12, No. 1, Date of access: 2015.

[7] [http://s.jstor.org/sici?sici=00931896\%28198523\%2912\%3A1\%3C144\%3ASTFWQO\%3E2.0. $\mathrm{CO} \% 3 \mathrm{~B} 2-2]$

[8] Dehdari, Ali, BitaDarabi, Mehdi Sepehrmanesh. "A Study of the Notion of Bhabhasque's Hybridity in V.S. Naipaul's In a Free State".International Journal of Humanities and Social Science, Vol. 3, 2013.

[9] Guerin, Wilfred L., Earle Labor, Lee Morgan, Jeanne C. Reesman, John R. Willingham. A Handbook of Critical Approaches to Literature. New York: Oxford University Press, 2005.

[10] Hatcher, Donald R..."Appealing to the Middlebrow Reader: Changes Made to Richard Wright's Black Boy”. Georgia Southern University, 2011.

[11] Hovad, Radovan. "Concept of Racism in the Novel Black boy by Richard Wright".University of Pardubice, 2010.

[12] Huddart, David. Homi K. Bhabha.New York: Routledge, 2006.

[13] Kunnie, Julian. "Richard Wright's Interrogation of Negritude: Revolutionary Implications for Pan Africanism and Liberation". The Journal of Pan African Studies, Vol.4, No.9, 2012.

[14] Kuriakose, Anisha. "Growing up Black in Wright's Black Boy”.Cochin University of Science and Technology, 2014.

[15] Mizutani, Satoshi. "Hybridity and History: A Critical Reflection on Homi K. Bhabha'sPostHistorical Thought". Zinbun, No. 41, 2008.

[16] Rahaman, Valiur. "Liminality, Mimicry, Hybridity and Ambivalent in Literary Speculations of HomiK.Bhabha”. Munich, Grin Verlag, 2010.

[17] [http://www.grin.com/en/e-book/163237/liminality-mimicry-hybridity-and-ambivalent-inliterary-speculations]

[18] Sawant, ShrikantB.“Postcolonial Theory: meaning and Significance”. S.R.M. College, Kudal, 2012.

[19] Sorensen, Rodger. "Black Boy: Concept/Vocabulary Analysis". Provo: Brigham Young University, 2009.

[20] Telgen, Diane. Ed. Richard Wright: Black Boy.USA: Gale, 1997.

[21] Umulkhulsum, ArijeYetunde, "Racism and Oppression in Black American Literature: an Example of Richard Wright's Black boy", University of Ilorin, 2011.

[22] Wright, Richard. Black boy: a record of childhood and youth, New York: Harper and bros., 1945. 